\title{
THE PRESENCE OF SPACE IN RICHARD HUGO'S MONTANA POEMS
}

Don Scheese

DEFINING "THE WEST"-along with providing some occasional embellishment - has long preoccupied speculators, geographers, and artists. Its boundaries have proven to be impermanent, its meteorology unpredictable, and its history imprecise. "Much energy has been spent in an effort to determine where the West begins," once commented Bernard DeVoto. ${ }^{1}$ The man whom DeVoto described as "the first American geopolitician,"2 William Gilpin, certainly expended considerable mental energy in his work of 1860 , The Central Gold Region, when he declared the entire Mississippi Basin a pastoral Canaan. ${ }^{3}$ Of course the continental vision of this pseudo-seer was as ambitious as it was inaccurate, but explorer-scientist John Wesley Powell was only partially successful in refuting the fatuous philosophy of Gilpin. In his 1878 Report on the Arid Region he attempted to inform the public of what it did not want to hear: the land between the 100th meridian and the Rocky Mountains - "the Plateau Province," as he called it-was a desert. ${ }^{4}$ Inadequate rainfall notwithstanding, the homesteaders and the cattlemen poured into the region as the rain seldom did, so that when artists such as Frederic Remington and Charles Russell captured on canvas the lifestyles of its inhabi. tants a new element was added to the definition: cowboy romance. ${ }^{5}$ This theme was perpetuated and strengthened in the Beadle Dime Novels of the 1880 s and '90s, ${ }^{6}$ and still later in the works of Zane Grey-so much so that "the Western" has become a distinct, if not highly regarded, literary genre. And though as early as 1917 Russell wrote, "The West is dead, my friend," the West qua Western - that is to say, the cowboy myth-prevails today. The resource-rich, boomtown West, complains Southwestern writer Edward Abbey, is still misperceived as "a vast, grand but empty stage whereon cavort, from time to time, the caricatures of myth and legend, noble cowboys and ecological Indians, sentimental gunfighters and whores with vaginas of pure gold."8 The history of defining "the West," in short, has been a history of myth-making and myth-shattering. Its bare-bones definition, nowfamiliar, almost formulaic, and not quite satisfactory, is offered by William Least Heat Moon in Blue Highways: A Journey Into America: 
The true West begins with the western state lines of Louisiana, Arkansas, Missouri, Iowa, and Minnesota. . . . It lies close to the hundredth meridian, the twenty-inch rainfall line, and the two-hundred-foot contour line. ${ }^{9}$

The problem with the definition is this: when confronted by it, anyone with geographical sensibility who has driven across the country must be struck by its poetical paucity. Moon himself makes this discovery while riding west along a highway in Texas, and then, in an epiphany, elaborates in such a way as to end all debate: "The true West differs from the East in one great, pervasive, influential, and awesome way: space" (p. 132).

Though one publisher has defined Western literature as "stories with trees in them," 10 space, rather than trees, has probably been more influential in shaping the writing of the West-witness the pivotal position occupied by The Big Sky. ${ }^{11}$ More recently, Norman Maclean, Ivan Doig, and Thomas McGuane have followed in this same tradition, ${ }^{12}$ revealing, as did A. B. Guthrie before them, their "powerful love for the sweep of plain and peak and sky."13 Additionally, they have further explored and revealed the oxymoronic possibilities of the West's "beautiful desolation." Consider, for example, this passage from McGuane's Nobody's Angel: "The West, the white West, a perfectly vacant human backdrop with its celebrated vistas, its remorseless mountains-and-rivers and its mortifying attempts at town building." 14

It is in this tradition too that at least some of the poetry of the late Richard Hugo must be placed, for though he also wrote of Italy, Scotland, and coastal Washington, his Western poems are dominated by the theme of space. As Hugo put it in "With Ripley at the Grave of Albert Parenteau": "This is the west and depth is horizontal."15 During the early 1970s he arrived in Missoula to direct the creative writing program at the University of Montana, and it was at this time that he began to write of "the true West"-and in particular about its geography. "I am a landscape poet," he revealed to William Kittredge in a 1981 interview. "I respond pretty much to the place where I live."16 Hugo's sense of space was shaped early in his life, living as he did near Puget Sound: to the west lay the unending horizon of ocean, and to the east, as he remarked in the autobiographical essay "The Real West Marginal Way," "The nation opened up forever from the top of Fourth Hill."17 But once engulfed by Montana's vast geography Hugo's sense of space was altered, since he now perceived it divorced from the sea: "Landlocked in Montana here / the end is limited by light."18 In the Montana poems of The Lady in Kicking Horse Reservoir, the emptiness of the West sometimes serves as a haven, more often as an oppressive force, but always-because we see the West through the keen eyes of the poet-it calls attention to the otherwise overlooked. Talking with Susan Zwinger in 1971, Hugo spoke of his own distinctive way of seeing: "I write about unpeopled worlds. . . . Decaying shacks, abandoned ranches, desolation, endless spaces, 
plains, mountains, ghost towns. They are right for my sensibilities."19 Yet, as a close examination of the Montana poems reveals, in these unpeopled worlds where "loneliness is endemic and contact always sporadic,"20 Hugo also frequently displays a need for people-in order to lend some human significance to the expanse of the West.

Frederick Garber, critic and friend of Hugo, observed in 1972:

What [Hugo] sees is usually seen most clearly in certain conditions. On the whole his is not a citified intelligence: in the city, he has said, it is difficult simply to see any one person or thing for very long, while in the country his sensibility is not flooded or forced to delete in order to understand. ${ }^{21}$

Least Heat Moon comes to a related conclusion concerning the relative ease of perceiving out West:

As the space diminishes man and his constructions in a material fashion, it alsoparadoxically-makes them more noticeable. Things show up out here. . . You can't get away from them by rolling up the safety-glass and speeding through, because the terrible distances eat up speed. (p. 132)

In "Driving Montana," Hugo does not want to roll up the window; instead, he rolls down the top of his Buick convertible and barrels along (The Lady, p. 61). Before reading this poem at Linn-Benton Community College in 1973, he commented:

Montana is a great state to drive in because there are no other cars. You just get out on these freeways and you don't see a car for ten minutes. You just drive and drive and drive. You put the top down and you get out on these freeways and the radio is on and God it's just a great feeling. ${ }^{22}$

"Driving Montana" is essential to a discussion of space in the Montana poems for a number of reasons. For one thing, it serves as a panoramic of Hugo's poetic turf: the speaker roams Interstate 90 from Billings to Butte. Additionally, it presents the poet-as-lone-stranger, an image integral to Hugo's poetry, and thus anticipates a later statement of his poetic philosophy: "No one / except poets know what gains we make in isolation." 23 Finally, in this poem space looms as large as it does in the West itself: "Tomorrow will open again, the sky wide / as the mouth of a wild girl. ..."

Hugo once said he saw the world "as a sad place without any people in it,"24 but he is ebullient throughout "Driving Montana," beginning with its opening line: "The day is a woman who loves you. Open." And, though the speaker is alone, he is accompanied more than adequately by the clear reception of the radio stations- "Miles from any town / your radio comes in strong, unlikely / Mozart from Belgrade, rock and roll / from Butte"-and memories of the day's events: "You remembered the ringing creek, / the soft brown forms of far off bison." Delightedly, he drives onward, immersed in "the dash of rabbits, soar of antelope, swirl / merge and clatter of streams." Having sought and found mental elbow room, the speaker is at peace: Man, Machine, and Nature commingle without conflict. Near the poem's end he 
relishes the thought that "you are lost / in miles of land without people, without / one fear of being found."

Those concluding lines, though, do suggest an ominous note: that the speaker has something to flee from. In "Bear Paw," whose setting is the site of Chief Joseph's 1877 surrender near Havre, space also seems to function as a haven-until the Nez Perce learn too late that their sense of freedom is a delusion (The Lady, pp. 76-77). In Montana, space and wind are often synonymous, and together they can act as an oppressor:

The wind is 95. It still pours from the east

like armies and it drains each day of hope.

From any point on the surrounding rim,

below, the teepees burn. The wind

is infantile and cruel. It cries 'give in' 'give in'

and Looking Glass is dying on the hill.

In contrast to the exuberant tone of "Driving Montana," the speaker here, momentarily assuming the consciousness of the Indians at the time of their final defeat, is in a less optimistic mood. The Nez Perce are betrayed:

That bewildering autumn, the air howled

garbled information and the howl of coyotes

blurred the border. Then a lull in wind.

$\mathrm{V}$ after $\mathrm{V}$ of Canada geese. Silence

on the highline. Only the eternal nothing

of space.

They believed "This is Canada and we are safe." But no refuge was offered by the expanse. So for today's visitor of this historical landmark, the only solace is to "Learn what you can." Even then, though, "The wind / takes all you learn away to reservation graves."

In "Bear Paw" it was the Nez Perce' inability to comprehend the artificial boundaries between nations, rather than space itself, which led to their deception and downfall. But the honesty of open spaces is a theme which Hugo pursued in other poems, as in "With Kathy in Wisdom": "And wind pours in on Wisdom / leaving false fronts really what they seem" (The Lady, p. 22). What is often exposed is a town beaten raw beyond saving, a community in which a prevailing sense of futility fuels despair. Such is the case in "Camas Prairie School":

The schoolbell rings and dies before the first clang can reach the nearest farm.

With land this open, wind is blowing when there is no wind. The gym's so ugly victory leaves you empty as defeat, and following whatever game you will remember lost, you run fast slow miles home through grain, knowing you'll arrive too late to eat or find the lights on. (The Lady, p. 68) 
Tragedy looms like the unconsoling sky because the distances between farms exacerbates the dangers of accidents and crimes, so

When your sister's raped

help is out of range. Father's far

from Mother and a far bell's

always ringing you can't hear.

Michael Allen, author of We Are Called Human: The Poetry of Richard Hugo, has pointed out that

Hugo gives us, as always, an image of the town seen from its underside, a town no self-respecting chamber of commerce would ever advertise, a town populated by drunks, angry boys, lonely travelers in bars, miners and their failed lives, workers who mistreat their wives. . . ${ }^{25}$

Why then focus on the Camas Prairies, the Dixons, the Ovandos of mostly unpeopled Montana? Answers to this question are available in the poems. "Silver Star" begins pessimistically enough:

This is the final resting place of engines,

farm equipment and that rare, never more

than occasional man. Population:

17. Altitude: unknown. (The Lady, pp. 20-21)

Then comes what might be interpreted as an emotional pivot: "For no / good reason you can guess, the woman / in the local store is kind." Hugo here reveals and revels in that however small glimpse of human community, the possibility to establish even fleeting contact with someone in a land Allen describes as "dotted by desertion-where the people have moved away, leaving the town ghostly, cut off, and isolated." 26 Other writers may write off the West; for Hugo it is the stuff of his best poetry. In "The Writer's Situation," an essay on the writing of poetry, he discloses that "I need little in the way of opportunities. Paper, pencils, a brief look at something most people ignore. . ." 27 In his poems, sometimes his reasons for choosing the subjects he did are expressed in cryptic terms: "There's a way of knowing why we go / to the places others pass by" ("The Sandbanks," White Center, p. 65). More telling is Hugo's famous expression of his poetic philosophy in "Ghosts at Garnet": "What endures is what we have neglected" (The Lady, p. 65).

Simply put, the vastness of the West allowed Hugo to see. And, in so seeing, he has helped define for his audience at least a part of the West. According to his poetics, then, tiny towns assume importance because they are so few; space lends to each a greater significance. So, however dismal a visit to a dot of a community like, say, Dixon may be- "You can go as out of business here / as rivers or the railroad station" ("The Only Bar in Dixon," The Lady, p. 72) - calling attention to it does serve to remind us of what still survives, albeit quite tentatively, on the margins of western Montana's lumber and mining economy; and perhaps makes us turn our heads 
in recognition when we encounter the reality of such a place outside the poems. By pointing out to us what we have ignored, Hugo alerts us to the rapid erosion of place so endemic to a region now beset by boomtown economics. A corollary to Least Heat Moon's "Things show up out here" is that when such artifacts disappear their absence becomes conspicuous-at least for those like Hugo who noticed them in the first place. Common to Least Heat Moon and Hugo is a distinctive mode of poetic perception, a way of seeing which allows them to imbue with significance the otherwise overlooked. There is, of course, the danger that we may become aware too late of things' disappearances; for example, in "St. Ignatius Where the Salish Wail," Hugo observes that the Flathead Indians' tribal customs are fast vanishing: "Every year / a few less live who know the Salish hymns" (The Lady, p. 10). On the other hand, to realize a loss is to be alerted to the possibility of future losses. So in "Montana Ranch Abandoned," although it may be too late to attempt a renovation of "cracks in eight log buildings"- since "even as you shored, / cars would still boom by beyond the fence, no glance / from drivers as you till the lunar dust" (The Lady, p. 62) - we can still appreciate the ruins and their significance, as well as thereafter acknowledge the existence of other formerly overlooked relics. In this sense, because it is a medium through which we are notified that something is disappearing, space updates our conception of the contemporary West by reminding us of what we are continually losing. Its ongoing, rapid economic and social facelift provided Hugo with plenty of material for his poems, as he made clear when he remarked, almost cavalierly:

Of course, one nice thing about America is that you're always losing. They're always tearing down something you love and putting something uglier in its place. So I don't think we'll run out of losses. ${ }^{28}$

However, rather than lament this kind of loss, Hugo put it to a different kind of poetic use, what Garber has termed "elegic conservatism""pouring over the past of the enduringly minimal, finding significance in the remains of what is no longer quite viable." 29

Entire towns can appear to be "no longer quite viable," though in what Hugo once said "may very well be the best poem I've ever written"30"Degrees of Gray in Philipsburg" (The Lady, pp. 78-79) — the speaker refuses to concede defeat to apathy and so sustains a successful quest for community and self-worth. Granted, the initial acquaintance with the town is hardly uplifting, after it is encountered only by chance-"You might come here Sunday on a whim"- - and as the speaker recognizes the depressing parallels that exist between it and his own life:

Isn't this your life? That ancient kiss

still burning out your eyes? Isn't this defeat

so accurate, the church bell seems

a pure announcement: ring and no one comes? 
Yet in a town surrounded and isolated by, to borrow McGuane's phrase, "remorseless mountains-and-rivers," it is possible to

Say no to yourself. The old man, twenty

when the jail was built, still laughs

although his lips collapse. Someday soon,

he says, I'll go to sleep and not wake up.

You tell him no. You're talking to yourself.

The car that brought you here still runs.

The money you buy lunch with,

no matter where it's mined, is silver

and the girl who serves you food

is slender and her red hair lights the wall.

The mostly monosyllabic words of this final stanza-seemingly simple, yet really incisive, pulsating-combine to create in the tone a psychological crescendo: We witness the elevation of the commonplace. Thus, Hugo manages to conquer the isolation, even desolation, of space, and transform it into consolation. The poem becomes a paean to the town-and the self. Hugo's fondness for out-of-the-way places continues to manifest itself in later poemsas did his affinity for the sea. In fact, evidence of competing affinities sometimes makes it difficult to determine whether Hugo preferred as his home the Washington coast or Montana. In "Letter to Wagoner from Port Townsend," he begins with an uncompromising statement of his love for the ocean:

Dear Dave: Rain five days and I love it. A relief

from sandy arroyos, buzzards and buttes, and a growing season

consisting strictly of June. Here, the grass explodes and trees

rage black green deep as the distance they rage in. I suppose

all said, this is my soul, the salmon rolling in the strait

and salt air loaded with cream for our breathing. 31 Letters, p. 32)

Yet in the same collection Hugo demonstrates his vacillation, for in "Letter to Goldbarth from Big Fork," he proclaims:

And I, who came from the seacoast,

who love the salmon, the damp air of Seattle, finally

have come to call this home. That means, when I say it, I lived

here forever and I knew it first time I saw it nine

years ago. Albert, Big Fork brings out the mountains in me. (pp. 59.60)

It may be that a letter-poem's place of composition determined Hugo's choice of a true home; the critic William J. Lockwood has argued that the Hugo perspective "was not after all defined by a fixed geography but by a mutable mind." ${ }^{11}$ But ultimately resolution was achieved through transposition, for Hugo managed to alleviate his longing for the ocean by transferring its features to landlocked Montana. Thus the vastness of the sea becomes the vastness of the valleys between the sky-rending Rockies and the plains east of the Divide. This transposition is evident when reading a later poem from White Center, "Open Country": 
It is much like ocean the way it opens and rolls. Cows dot the slow climb of a field like salmon trawls dot swells, and here or there ducks climb on no definite heading. Like water it is open to suggestion, electric heron, and every moon tricky currents of grass.

And you come back here where land has ways of going on and the shadow of a cloud crawls like a freighter, no port in mind, no captain, and the charts dead wrong. (p. 17)

NOTES

1 Bernard DeVoto, "The West: A Plundered Province," Harper's, August 1944, p. 356.

2 Bernard DeVoto, "Geopolitics with the Dew on It," Harper's, March 1944, p. 315.

3 William Gilpin, The Central Gold Region, The Grain, Pastoral, and Gold Regions of North America with Some New Views of Its Physical Geography and Observations on the Pacific Railroad, rpt. in part in The American Landscape: A Critical Anthology of Prose and Poetry, ed. John Conron (New York: Oxford University Press, 1974), pp. 372-77. For commentary on Gilpin's role in promoting the settlement of the Mississippi Valley, see DeVoto, "Geopolitics," pp. 313-23; Henry Nash Smith, Virgin Land: The American West as Symbol and Myth (Cambridge, MA: Harvard University Press, 1950), pp. 35-43; and Wallace Stegner, Beyond the Hundredth Meridian: John Wesley Powell and the Second Opening of the West (Boston: Houghton Mifflin Co., 1953), pp. 1-6.

4 Stegner, pp. 209-31.

5 See, for example, Harold McCracken, Frederic Remington: Artist of the Old West, introd. James Chillman, Jr. (Philadelphia: J.B. Lippincott Co., 1947); Harold McCracken, The Charles M. Russell Book: The Life and Work of the Cowboy Artist (Garden City, New York: Doubleday and Co. Inc., 1957); Brian W. Dippie, Remington and Russell (Austin: University of Texas Press, 1982); and Masterpieces of the American West: Selections from the Anschutz Collection (Denver: A. B. Hirschfeld Press, 1983), plates 40-43, 45.

6 Smith, pp. 90-111.

7 Quoted by Russell Martin, "Writers of the Purple Sage," New York Times Magazine, 27 December 1981, p. 20.

8 Edward Abbey, Abbey's Road (New York: E. P. Dutton, 1979), p. xix.

9 William Least Heat Moon, Blue Highways: A Journey Into America (Boston: Little, Brown and Co., 1982), p. 131. Subsequent references to this edition will appear in the text of the essay.

10 An anecdote related by Norman Maclean in his acknowledgements to A River Runs Through It and Other Stories (Chicago: University of Chicago Press, 1976), p. ix.

11 A. B. Guthrie, The Big Sky, introd. Wallace Stegner (Boston: Houghton Mifflin Co., 1965), p. xi.

12 Maclean, especially the title novella; Ivan Doig, This House of Sky: Landscapes of a Western Mind (New York: Harcourt Brace Jovanovich, 1978); and Thomas McGuane, Nobody's Angel (New York: Ballantine Books, 1979).

13 Wallace Stegner, Introd., The Big Sky, by A. B. Guthrie (Boston: Houghton Mifflin Co., 1965), p. xi.

14 McGuane, p.126.

15 Richard Hugo, White Center (New York: W. W. Norton \& Co., 1980), p. 9. Subsequent references to this edition will appear in the text of the essay.

16 William Kittredge, "Dialogue with Richard Hugo," Northwest Review, 19, Nos. 1-2 (1981), p. 139. 
17 Richard Hugo, "The Real West Marginal Way," in American Poets in 1976, ed. William Heyen (Indianapolis: Bobbs-Merrill, 1976), p. 123.

18 Richard Hugo, "The Lady in Kicking Horse Reservoir," in The Lady in Kicking Horse Reservoir (New York: W. W. Norton \& Co. 1973), p. 73. Subsequent references to this edition will appear in the text of the essay.

19 Susan Zwinger, "Remarks by Richard Hugo," New Letters, 37 (1971), p. 16.

20 Frederick Garber, "Large Man in the Mountains: The Recent Work of Richard Hugo," Western American Literature, 10 (1975), p. 205.

21 Frederick Garber, "Fat Man at the Margin: The Poetry of Richard Hugo," Iowa Review, 3 (1972), pp. 58-59.

22 Richard Hugo, The Writer and the Real World: A Conference Held March 19-24, 1973, at Linn-Benton Community College, Parts 1 and 2 (cassette recording).

23 Richard Hugo, "Letter to Birch from Deer Lodge," in 31 Letters and 13 Dreams (New York: W. W. Norton \& Co. Inc., 1977), p. 62. Subsequent references to this edition will appear in the text of the essay.

24 Zwinger, p.16.

25 Michael Allen, We Are Called Human: The Poetry of Richard Hugo (Fayetteville, AR: University of Arkansas Press, 1982), p. 16.

26 Allen, p. 18.

27 Richard Hugo, “The Writer's Situation," New American Review, 11 (1971), p. 222.

28 Thomas Gardner, “An Interview with Richard Hugo," Contemporary Literature, 22 (1981), p. 145.

29 Garber, "Fat Man," p. 61.

30 Hugo, The Writer and the Real World, Parts 1 and 2.

31 William J. Lockwood, "Richard Hugo's Return to the Pacific Northwest: Early and Recent Poems," in The Westering Experience in American Literature: Bicentennial Essays, eds., Merrill Lewis and L. L. Lee (Bellingham, WA: Bureau for Faculty Research, Western Washington University Press, 1977), p. 161. 